The Geographical Journal of Nepal

Vol. 14: 81-112, 2021

DOI: https://doi.org/10.3126/gjn.v14i0.35552

Central Department of Geography,

Tribhuvan University, Kathmandu, Nepal

\title{
Territorial mobility in traditional societies of Bhojpur, Majhkirant
}

\author{
Dhyanendra Bahadur Rai ${ }^{1 *}$, Bhim Prasad Subedi ${ }^{2}$, Hriday Lal Koirala ${ }^{1}$ \\ ${ }^{1}$ Central Department of Geography, Tribhuvan University \\ ${ }^{2}$ Chairman, University Grants Commission, Kathmandu \\ *Corresponding author: dbrrai@yahoo.com
}

Received: 15 November, 2020; Accepted: 28 December, 2020; Published: March 2021

\begin{abstract}
Territorial mobility is an inherent element for survival and it is a common feature of rural area. It reflects the whole life style and livelihood pattern of a community. Therefore, territorial mobility could be an important aspect of living and coping with external world particularly in the traditional communities of rural Nepal. This paper seeks to explore the changing territorial mobility among the Rai people from Sampang area of Bhojpur district in Majhkirant region. The mixed method, both quantitative and qualitative is adopted for data collection. The formal instruments such as household survey, focus group discussion, mobility register, and the folk sources such as folk songs, local sayings, proverbs, local events were used to generate the data together with the observation method as well. Findings indicate that all forms of mobility of Majhkirant people in which they participate can be summarized into two categories i.e. basai sarai and ghumphir. The long-term moves such as Muglan bhasine, Madhesh jharne, ghar khana jane, desh nikala hune are the specific types of basai sarai. On the other hand all types of short-term mobility normally of short distance are part of ghumphir which are common forms of movement among the people of this area. The feature and frequency of various types of moves vary among Rai and non-Rai community and it also differs over time and space. For example, pitri garna jane, nwagi garna jane, mang garna jane, kaliya jane are more noticeable among Rai community while tirthayatra, chardham jane, astu selauna jane, puranma jane, katha sunna jane are commonly found among non-Rai (Brahmin community). Similarly, moves such as, Lahur jane, phukna jane, ghar banauna jane are associated with Rai people whereas moves like jajamani garna jane, puranma jane, katha bhanna jane are primarily confined to Brahmin community. Many other forms of localized moves were also noticed and all of them had their linkages with participation in socio-cultural, professional, political and economic spheres of rural life. Some moves associated with kinship and neighborhood network as well as
\end{abstract}


obligatory are commonly found in all community. In addition, many of these move are age-sex specific, others are associated with occupation of the person and with changing aspiration of people including changing geography of development activities.

Keywords: Territorial mobility, moves, migration, traditional society, Rai community

\section{Introduction}

Territorial mobility refers to all forms of movement by people and such movement takes place at different spatial and temporal scales and reflects a wide range of underlying factors and motivations (Alexiades, 2009). Mobility is an intrinsic element in human life as a continuous and enduring process from the very beginning together with human history in different forms (Lemos, 2010). It is also a way of life-style and life pattern in a traditional society (Subedi, 1993). So, it has become as the regular activities of common people. Mobility remains as an important elements of diversified and flexible strategies of an individual and group of people (Alexiades, 2009). Most of the mobility are carried out for maintaining social process; relationships, responsibility, interaction and social identity (Memmott, Long, Bell, Taylor \& Brown, 2004). Various studies (Young \& Doohan, 1989; Memmott, Long, Bell, Taylor \& Brown, 2004) to date have considered the mobility aspirations of indigenous people. Territorial mobility can be understood from different perspectives. The major perspectives are caste/ethnic, socio-cultural, economic, historical, spatial, and so on. Human mobility has different forms with reference to, for example, distance, duration, and frequency (Bell \& Ward, 2000), and various forms of mobility may have different implications for people's daily activities including sense of territorial belonging. It is true that people are mobile on their life trajectory continuous over space and time while they settle down and become nonmovers and vice-versa. Movers refer to all people who travel between places for short or long periods and for a number of reasons via numerous channels and mechanisms and who may fall under various administrative regions.

Demographers usually consider to the complex interplay "push-pull" factors from one place to another as the mechanism causing the decision to move. The push-pull factors work at different levels of social organization: personal, familial, communal and regional (Alexiades, 2009). Neo- classical economists suggest differential status of wage between countries and cost of migration while it depends upon personal decision after perceiving (Sirkeci and Cohen, 2016). Basically, macro level forces are influential and widespread for migration. World system theory addresses international migration as the result of economic globalization. Processes of globalization, along with an increasing awareness of such process further highlight the importance of different forms of mobility, and several academics argue that practices and representations of 
mobility are crucial for understanding contemporary societies (Cresswell, 2006; Sheller \& Urry, 2006; Urry, 2000). Mobility has increased excessively now-a-days due to the globalization and modernization everywhere in every community (Heide, 2001).

In the context stated above, the present paper attempts to shed light on the traditional rural society considering the history and socio-cultural aspects focusing on native Rai community in comparison with other social groups such as Brahmin, Tamang, Dalits etc. The research focuses on Rai community due to its special and unique type of cultural practices and customary life style, particularly with a changing situation of the whole social milieu as well as the change in political power relation of the nation.

\section{The study area}

The study area, Sampang lies within ward number seven of Shadananda Municipality of Bhojpur district covering an area $21.82 \mathrm{~km}^{2}$. It has a rugged topography, elevation ranging from 635 to 2570 meters within a short physical distance. Historically, this region is associated with Majhkirant which is known as ancestral land of Kirant Rai people.

The study is mainly concentrated in Chhaplegaun within Sampang in which Khordanda, Toribar, Tarbar, Bakchhama are encompassed as small hamlets or Tole in Nepalese context. The total population of this area is 496 with 254 male and 242 female. Kirant Rai people are the dominant population in this village which occupies about 82 percent population followed by Tamang, Dalit, Brahmin, Bhujel and Sherpa communities. Almost 74 percent people follow Kirant religion and all of them understand and speak Nepali language. Most of the people (79 percent) of Sampang are engaged in agriculture with livestock farming as their primary occupation. Major cereal crops are rice, maize and millet while cash crops are orange, cardamom and rudraksha (eloecarpus sphaericus). Presently, people are motivated towards cash crop farming and other sources of cash earning such as petty business, vendor, small enterprises, semi-skilled labor in the village as well as foreign employment particularly in Gulf Countries and Malaysia. Recruitment in British army was traditional occupation as prevalent practice especially in Rai community in the past but this trend has decreased now. 


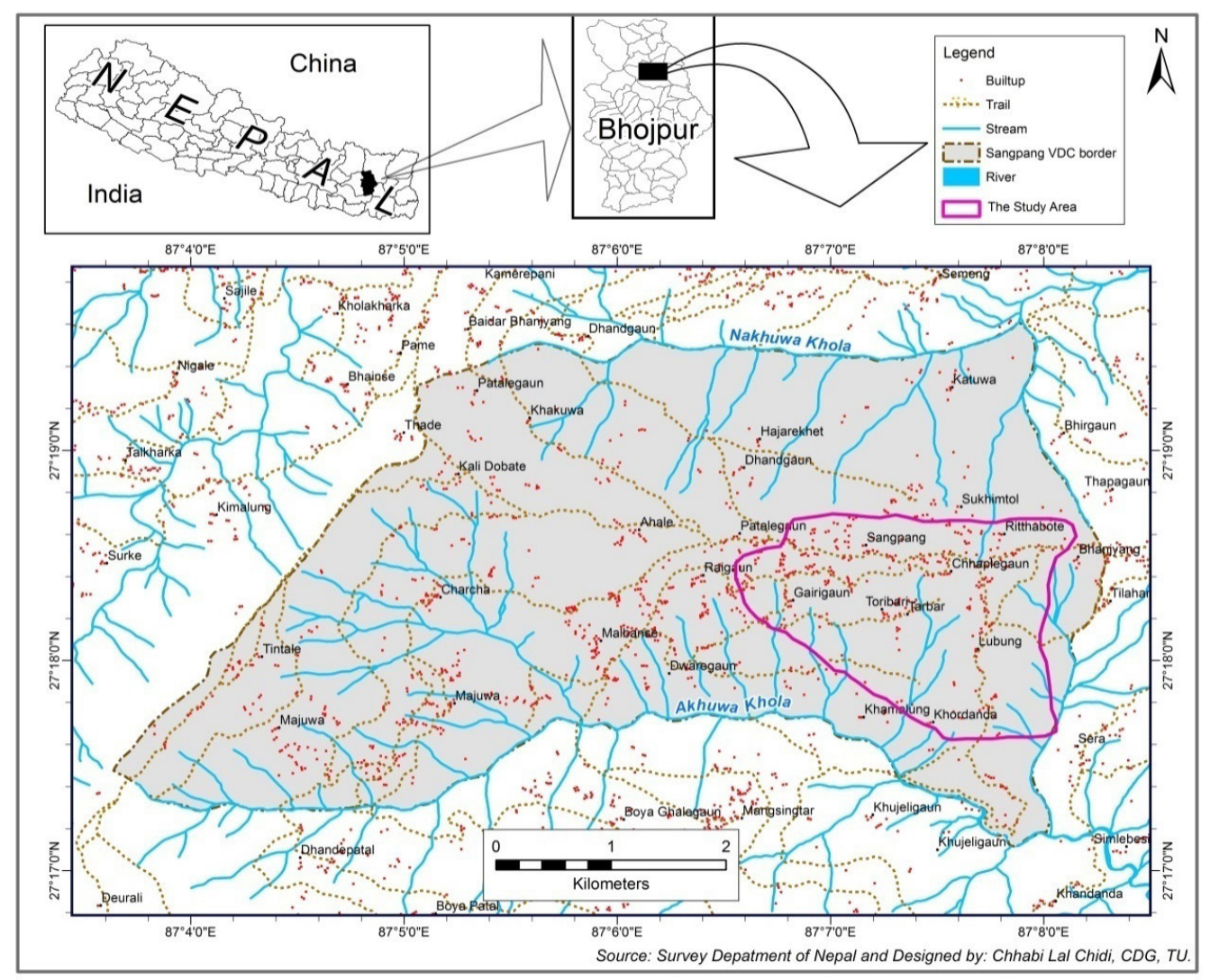

Figure 1: Location of Sampang area in Bhojpur district

\section{Methods and materials}

The research methodology, adopted in this study, is a mix of qualitative and quantitative methods. Interpretivism, one of the methods of qualitative research is helpful for gathering data in the research that allows opportunity to study the possibility of multiple realities of participants in the settings. Apart from information collected from formal instruments such as household survey, mobility survey and focus group discussion, the folk sources such as collecting myths, legends, local sayings, and local events obtained from senior citizen, with the help of long and deep interview plus observation and interpretation of different events have been main sources of information in this research. A total of 126 households were surveyed for this study. This included households currently living in Sampang (91) and those as part of tracer households in Tarai area and Kathmandu valley (35). Apart from survey instrument, informal discussions and interactions were carried out. The intention of these informal instruments was to obtain insights so that perception associated with mobility and its meanings of socially constructed realities of traditional 
society are drawn and interpreted logically. A mobility register was established to record the movement of people which gives a real picture of the mobility of people within a certain distance over time and space. Moreover, it presents causes, purposes, and frequencies of movement from home and reach. Mobility registers were prepared in twenty households in Sampang area. The registers were established for ten months, considering both seasons (winter and summer) from October to July. Registers were maintained by the normally educated members of the households. The register recorded all moves of the household members age 15 and above within the specified period.

\section{Results and discussion}

\section{Typology of territorial mobility within Sampang area of Majhkirant}

Mobility has different meanings in different perspectives. It is a way of life style and life pattern in a traditional society. So, mobility is determined by the socio-economic, cultural, and political condition of any community. There are various types of rural territorial mobility in the context of Nepal where many castes and ethnicities are found in traditional lifestyle from the very beginning. Mobility is a continuous process of lifelong phenomena of traditional society that is directly and indirectly linked with their daily activities.

Nepali typology of rural population movement was originally developed by Subedi (1993). He acknowledges that territorial mobility in traditional societies is often complex and confusing and that an analysis of short-term mobility needs to adopt a working definition based on local reality. For this, he takes a minimum duration of one night away from home to identify short-term mover. This one night stay was primarily based on the local people's view that it is the minimum duration of absence to which the household members feel the absence of their members. This study adopts the same criteria and considers absence of at least one night away from home as criteria for identifying movers of the households. The identification was based on the recorded moves of all family members in the household mobility register.

Subedi (2000) identified two forms of Nepali mobility namely Basai sarai (relocation) and Ghumphir (circulation). Several types of mobility within basai sarai and ghumphir were identified from eastern Nepal. The present study by adopting the framework of Subedi (1993) further explores additional categories and elaborates similar the categories as they mirror in the traditional societies of Bhojpur, Majhkirant. 


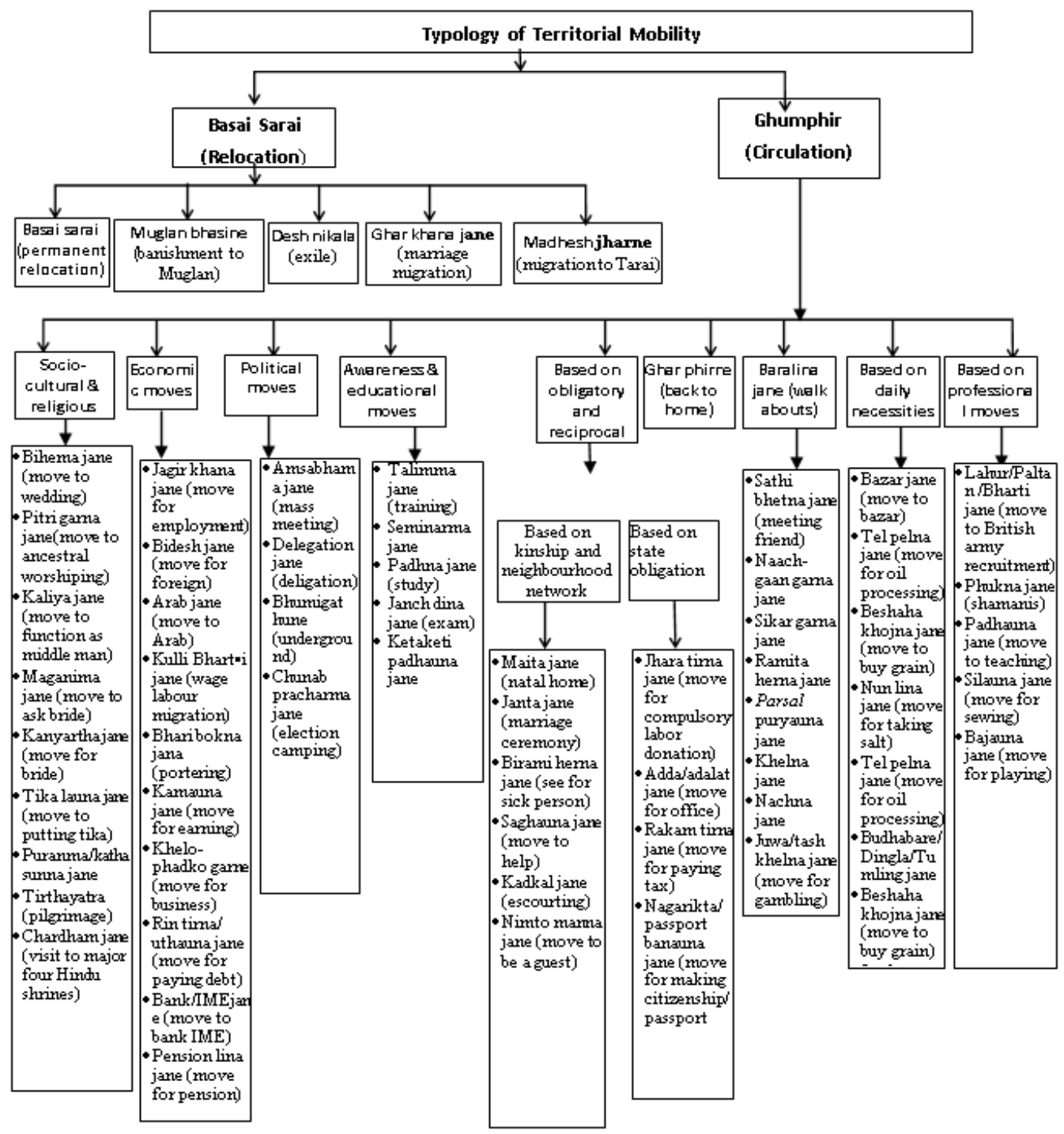

Figure 1: Typology of rural territorial mobility (after Subedi, 1993)

The basic characteristics of territorial mobility in the rural societies and in the traditional communities are analogous with Subedi (1993). However, the natures of mobility are clearly different on the basis of time and space, the intensity of certain mobility has increased, some has decreased, and some has disappeared recently. Similarly, various kinds of mobility are appeared in a modified form in the context of destination, duration, frequency, participants, volume, and so on. For example there is no desh nikala (exile) type of basai sarai (permanent relocation) now which were common in the past. 
Similarly, in the latter days, it has flourished the moves such as bides jane (move to abroad) in Nepal. The moves related to economic, professional, political, educational and livelihood have been expanded in terms of volume and distance in the present days. Some of the sociocultural and religious moves may be distinct due to caste or ethnic background of the study area. The typology of territorial mobility within Sampang area of Manjhkirat is categorized as the followings:

\section{Basai Sarai (permanent migration)}

Basai sarai includes those forms of mobility that primarily involve permanent relocation of households and individuals from particular place to other new place (Subedi, 1993). Relocation may be within a national political boundary or may be beyond it. It has also several meanings and dimensions over the years depending upon time and situation. The main feature of basai sarai is in its permanency. Basai jane (relocation), Muglan bhasine (movement out of social out casting), and ghar khana jane (marriage migration) are a permanent type of basai sarai having no possibility of reversibility (Figure 1). Similarly, bhagne (escaping), Madhesh jharne (migration to Madhesh) and bideshine (migration to beyond the country) are also basai sarai but those have the reversible nature. In the distant past, basai sarai was often taken as a negative connotation. But now, it is not taken as in the past and it has become a common phenomenon in Nepalese society.

Literature is the mirror of society, it reflects not only present but also past event of the society. In Nepalese literature, there are several examples that represent the basai sarai prevailing in our society from very beginning (Bangdel, 2005; Bhattarai, 2031; Chhetri, 2014). The passage extracted from famous social novel written by Chhetri (1957) in Basai has referred to the real causes and consequences of basai in Nepalese society, especially in five to six decade ago. It is the real story of emigrants resulting from a contemporary socioeconomic condition of eastern hill regions of Nepal. A small piece here, expressed convincingly by Dhane, a prominent character of the novel Basai, to his wife Maina during the miserable moment of relocation:

Prepare a kumlo-kuturo (package) now. We should go out tomorrow in jhismise (dawning). How to leave this ancestral place? It has wetted from sweat of own forefathers who have been living here from generation to generation. There is no meaning of weeping and no meaning of crying. What are our means and what is our way? What to do, if it is written by God in the head. (p. 59) 
The whole story of this novel describes the real picture of a painful situation of migrants as the result of feudal exploitation in the village. The landless and homeless condition after the exploitation by landlords in the Nepalese rural society was the cause of the mass migration towards Assam of India. It was the common phenomena in the Nepalese rural society. The main character of Basai novel, Dhane, represents the situation of migration and migrant people in the rural areas of Nepal. Similarly, Rane, Dal Bahadur, Myauchi, Masini, and Bhujel Mahila of Muluk Bahira written by Bangdel (2005) and Sutar, Pakhe Shahila, and Karki of Muglan written by Bhattarai (2031) are the representative characters of emigrants from Arun Khola (Arun Valley) who are compelled to migrate for livelihoods in different parts of India. Such moves were called Muglan jane, Aasam jane (move to Assam), kaman jane (move to tea estate), ara kaatna jane (move to eastern part of India for sawing timber), bagada khana jane (move to rice producing area). Wandering of them to different places like Assam, Gumpahad, Bhutan, Darjeeling to Burma for searching works reflect to the real situation of movers in new places. Along with the written Nepalese literature, songs and folksongs also carry real meaning of rural society at that time. The song always humming in the rural areas about thirty years ago-basai hidneko tantile, basneko mana ruwaunchha, lakhaunko laagi ujaad chha yo desh, muththi bharlai ta swarga chha (seeing the caravans of migrants makes heart break of stayers, this place seems like desert for millions of people and is heaven for a few people who can be counted in fingers) indicates the mass migration of Nepalese rural people due to the over exploitation and unbearable tyranny of limited persons upon poor common people in the village (see, Rai 2017). Such events are common in the eastern hilly region of Nepal. The former context of the Basai novel and its main character Dhane, and the second context of the Nepalese popular song basai hidneko tantile, clearly points out the enforced circumstances for migration. Similarly, it was never matter of a comfortable and pleasant moment for migrant people. Thus, migration is the result of injustice, over tyranny and exploitation and it was viewed as the Marxist point of view in Nepalese society.

Different kinds of a forceful situation create sometimes the cause of migration to a person. This form of migration falls in Muglan bhasine/pasne/jane (migration to unknown places due to serious social accusation. This word is used in the context of fleeing away by king. In the latter days, it is experienced that the demonstration of un-apologized misconduct of a person is responsible for this. So, it gives a negative meaning. This type of movement of people is the starting point of deserting life from long-rooted history of an individual as well as whole family. Such kinds of migration encompass an individual or a group departure. An extreme frustration in practical life also compels people to leave their own place. When one cannot see any alternative ways of their livelihood sustaining and living situation in the place, individuals make a plan to 
move towards an unknown and distant place, called Muglan bhasine in a local language. Various contextual events of Muglan bhasine are presented in the research of Subedi (1993) in the eastern hill of Nepal. This term, Muglan bhasine, has now been used less frequently. However, the researcher has found one such case in a Rai community in Chhaplegaun, Sampang where a woman, Suryawati Rai (aged 46) narrated her family situation as follows:

Suddenly one night, my husband left home. He was escaped (Muglan bhasiyo) with a woman (aunt) in our own clan whose husband had died. The fact is that the woman (kaki) became pregnant. I did not enquire about him. I suffered many difficulties in this period. My daughter died of heart problem. Some people said that he is now living in Darjeeling by getting remarried with a Tamang girl. Suddenly, he came last year in this home. I first of all asked, why did you come here after such a long time? A real thing is that he has come here remembering Kul Pitra, not me. His child from Tamang girl was sick. He has been informed by bijuwa in Darjeling to do kul pitra (praying ancestral god). And he did pitra, stayed fifteen days in my home, and then returned to Darjeeling.

Such events occur rarely and unexpectedly in the villages which makes villagers surprise and sometimes sad. It is the serious matter of prestige and dignity of whole family and relatives not only a related person. Some of the migrant people are lost and mislaid in the foreign land. Some return home after long time while it is supposed that people forget the event.

Many people who moved to Muglan in the past for sustaining livelihoods disappeared for many years in the external land. Disappearing sons for long time in foreign land is considered as a common phenomenon in Nepalese society, but the situation is not same in the case of daughter. Walking in the alien land is necessary for sons to make themselves more practical and clever. The person, who has wide and varied knowledge of external world, is known as desh khai sesh bhayako means experienced through high mobility.

Another type of territorial movement is ghar khana jane (marriage migration) remains as a common practice in Nepalese society as well as in India. Bride is sent to groom's house as a daughter in law, called ghar khana jane in a pure Nepalese term. The movers are especially at the young age below ten in the past, but now this age is growing up around twenty and above. Despite departure of bride permanently, the cultural ties remains inalienable with natal home through frequent visit. The popular songs buzzing 
in our ears also express this meaning. The songs "maiti ghar timro hoina, parai ghar jau, bida lii kahilekahi janma ghara aau" also indicates the compulsion of girls' departure through marriage - meaning that parents home is not their real home; go to others' homes; and come birth home repeatedly taking permission. Getting marriage is the responsibility of baau-maiti (guardian) and maintaining a relation through their visits in festival and social ceremonies is the duty of married chelibeti (sisters).

The term bhagne (escaping) is a kind of a territorial movement as the result of social misconduct, such as, marriages without parents' consent, and police case in the events like a murder, sexual abuse, fighting and theft. Among the different types of marriage, bhagne is prevalent in the Nepalese society particularly in ethnic community. The person who participate in bhagne, may disappear from the sight of community for short period to long, it depends on nature of misconduct. Bhagne is similar to Muglan bhasine but not at the same scale. The society gradually forgets the case and event; the bhaguwa (one who escapes) may return home and may settle in the society. The people moving from home as an escaping often reached different places of India and work as kulli bharti (wage labor). They reached Assam working in gaigoth (cowshed), tori kheti (mustard farming), and kuyanr kheti means sugarcane farming (see Muluk Bahira written by Bangdel, 2005 and Muglan written by Bhattarai, 2031). The word Tori Lahure (workers of tori farming in Assam) became popular from that time till now. The context of Tori Lahure came into practice when the workers of mustard farming returned to the village in a stylish way like a Lahure of India and Malaya (British). Later on, this word became popular in the society used in the ridiculous sense for showing over smartness tendency of a person. Some of the youths leave the village to fulfill their curiosity of outside world in allare-ballare (teen agers) age without any concrete purpose. Some of the youths of Brahmin family escaped from village by taking a purpose of education in Banaras if the family does not agree on this. It indicates a strong desire towards Sanskrit education in Brahmin community at that time while there was no opportunity of taking education in the village. During the fieldwork, a Kaphle, Brahmin aged 72 told how he started his life by escaping from village. He says:

I had heard many things about Banaras when I was about eleven and twelve years old. I told my desire to my parents regarding my study on Sanskrit in Banaras frequently. However, I did not see any sign of fulfilling my desire. I was thinking of how to escape from home. One day, I went to Ahale to carry potato with my mother. We returned from Ahale taking potato in the sack. I was following mother on the way. Mother was a little far from me. At the same time, I put my sack in chautara (resting platform). Then, I ran through the jungle being 
invisible from the eye of mother. I reached Dharan in three days on foot. I had only ten rupees picked from my father's pocket. I went to Banaras after one month. I returned from Banaras after studying Uttar madhyama (equivalent with certificate level of education).

Another common typology of migration, Madhesh jharne, is migration to Tarai area. It has a regional dimension of migration. Tarai was a major destination place from mountain and hill because of fertile land and other economic possibilities. So, Tarai migration was mainly motivated to the place from the economic point of view, as also reflected on Nepalese folk song such as Madhesai jaunla ni dhan kamai lyaunla $n i$ lallauri billauri (moving to lowland, for earning money in hand). In the past, Tarai migration was male specific particularly for an agricultural purpose. But today, the migration has multipurpose and multidimensional aspect. Basically, the mass migration from hill and mountain to Tarai took place after the eradication of malaria in Tarai (Kansakar, 1974).

The next form of migration is bidesine (move to foreign land), can be categorized into desh nikala (banishment) and bidesh palayan (brain drain). Desh nikala was in practice in the past due to the political cause especially during the Rana and Panchayat periods when autocratic system was established (Kansakar, 2005). The punishment of banishing was used for opponent political leader. Opponent political leaders were exiled for many years especially in India as a political refugee. Some got punishment for banishing and some made self-decision for banishment due to the danger of entrapping in false case and danger in life too. Basically, the politicians who engage in opponent politics, participate in such moves. Similarly, bidesh palayan/bideshine is self-motivated moves abroad for good opportunities there. The movers are especially high educated, Green card, and PR holders, as well as UK armies and their children. In this regard, an exBritish Lahure says openly as following;

"British government has made a provision of settling in UK for exBritish armies and their dependents. After that provision, majority of the ex-servicemen with their offspring, have left the country. It is not our eagerness but we are compelled to leave home country (bidesh palayan) for the children's desire. Today's new generation feels happy there but we don't feel so."

A large number of families of ex-British in Sampang, participated in bidesh palayan moves as a new trend of migration in Rai community. Basically, new generation is interested for this migration but their parents feel happy to stay in Nepal and want to die here. 
A popular moves bidesh palayan, is in ascending trend in Nepalese society especially well-educated youths in the recent days. A large number of young educated people of new generation are interested towards external world for earning money and getting knowledge and skills as well as for grabbing new opportunities there. America, Europe and Australia have become as new destination countries for this purpose. In another term, the moves of educated people in this category is called "brain drain" means flow of capable person which is not good sign for the future development of the country. In this migration, there is maximum chance of permanent relocation of a person in abroad.

\section{Ghumphir (short-term mobility)}

The term ghumphir means the movement of people within a certain distance and a period of time for different purposes. Dulghum, ghumgham, and ghumai phirai are some of the synonyms of the ghumphir used in Nepalese rural society. Its main feature is circulation. Mostly, circulation takes place within home territory. There are varieties of ghumphir, such as socio-cultural, religious, economic, educational, political, obligatory, reciprocal, gaunbensi garne (transhumance), baraline (walkabouts), ghar phirne (back home) and so on. The forms of mobility captured by the concept of ghumphir can be subcategorized into other various forms on the basis of their nature and characteristics, experiences from traditional society of Sampang area.

Table 1: Categories of movement based on purpose

\begin{tabular}{|c|c|c|c|}
\hline Purposes & Activities & At past & At present \\
\hline $\begin{array}{l}\text { Socio-cultural and } \\
\text { religious events }\end{array}$ & $\begin{array}{l}\text { Wedding, death ceremony, Chhewar, Sakela, Mang } \\
\text { garna jane, Panchawali, Kaliya jane, festival, Puranma/ } \\
\text { Sharadma jane, chardham, astu selauna jane etc. }\end{array}$ & 30.5 & 20.0 \\
\hline Economic & $\begin{array}{l}\text { Khelo phadko garne, Bank/IME jane, pension lina jane, bhari } \\
\text { bokne etc. }\end{array}$ & 13.8 & 16.5 \\
\hline $\begin{array}{l}\text { Political/official/ } \\
\text { administrative }\end{array}$ & $\begin{array}{l}\text { Party meeting, delegation, mass meeting, training, } \\
\text { workshop, Adda/office jane (making citizenship, } \\
\text { passport, revenue paying, land registration), Adalat jane } \\
\text { (court case etc.) }\end{array}$ & 10.0 & 14.5 \\
\hline Livelihood/occupation & $\begin{array}{l}\text { Lahur jane, bidesh jane, jagirma jane, wage labour, lek- } \\
\text { bensi/gaun-bensi garne (transhumance) etc. }\end{array}$ & 12.0 & 12.2 \\
\hline $\begin{array}{l}\text { Education/health/ } \\
\text { communication }\end{array}$ & $\begin{array}{l}\text { Kharcha puryauna/ketaketi padhauna jane, move for } \\
\text { schooling, move for exam, hospital jane and phone garna } \\
\text { jane etc. }\end{array}$ & 8.0 & 16.0 \\
\hline Entertainment & $\begin{array}{l}\text { Hunting, fishing, gambling, playing, dancing, Mela/ jatra } \\
\text { jane etc. }\end{array}$ & 5.7 & 2.0 \\
\hline Based on daily necessity & Sauda garna/kinmelma jane, bajar jane, mal lina jane, etc. & 9.0 & 14.8 \\
\hline Obligatory & $\begin{array}{l}\text { Maita jane, Aspatal jane, janta jane, Jhara tirna jane, } \\
\text { Marimarauma jane etc. }\end{array}$ & 11.0 & 4.0 \\
\hline Total & & 100 & 100 \\
\hline
\end{tabular}

Source: Mobility registers, 2014; Field Survey 2014 and 2019 


\section{Moves related to socio-cultural and religious purpose}

This type of moves includes the movement motivated by socio-cultural and religious reasons called ghumphir in the local context. About 31 percent people were involved in it at past and 20 percent in the present (Table 1). Most of the socio-cultural and religious moves are related with birth, death, wedding as well as festivities and are performed within a short distance and short period. The research conducted by Taylor (1998) has suggested the same situation of moves in aboriginal society in Australia. Mela bharna/herna jane (participate in fair), tika launa jane (move for putting tika), cheli puryauna/lyauna jane (move to reach/bring sisters), bhikshya dina jane (move for giving alms in thread wearing ceremony), and mari marauma jane (participate in dead ceremony) belongs to some sociocultural moves within about all caste and ethnicity. Similarly, these terms - pitri garna jane (ancestral worship), raksi khana jane (move for engagement process), rit puryauna jane (move for carrying essential things on bride asking moment), kaliya jane (move for marriage proposal as mediator), and maganima jane (move for asking bride as formal way) are related particularly to Rai community. Mela bharna/herna jane (participate in carnival) is also an important movement for a sociocultural life in the village. Various purposes are fulfilled through mela-jatra (carnival) in the rural life. Earning merit by worshiping god and goddess may be a main aim in most visitors of Brahmin-Chhetri community. Most of the people visit mela as said in Nepalese proverb: Pashupatiko jatra, sidrako bepar, means to kill two birds with one stone. K. Adhikari, aged 56 of Sampang found during Balachaturdashi Mela at Dingla says:

I have been continuously visiting Dingla, especially in mela. I do not miss every Balachaturdashi and Ramnawami mela. I departed at 7 o'clock from home in the morning without having anything. I came here at 10 o'clock and prayed in the temple. I met relatives and purchased clothes for children.

This shows the multiple purposes of visiting for movers in mela. The purpose depends on people's interest, age, sex, social background and so on. Taking entertainment was one of the major purposes of participating in mela in the past especially for young people while there was not available other mode of entertainment. Its importance is great for maintaining customary life-styles and life process. Most of the mela which are regularly observed at the confluence of the river, well-known hill tops, and historical and religious sites. 
Various kinds of socio-cultural moves have distinct types of features. Some moves are associated with a certain time, months, season, and geographical boundary. And some are wider in its dimension. For instance, season-specific ritual activities have limited geographical expansion and social periphery. Likewise, wedding ceremonies have a wider geographical boundary and but a specific time. But the moves, related with death, illness and causal events, have no limitation of season and geographical limitation. Regular annual activities such as Ubhauli/Udhauli (Sakela/Kirant festival) and Mang (ancestral god) have no wider participation.

Various religious deeds such as Mang garne (ancestral worshiping) and Nwagi (offering of new harvest) are performed by Rai community which are based on Mundhum (Veda of Kirant), known as a main ritual work on the basis of seasonal cycle. Performing mang is main duty of each Kirant's descendants. So, people of Sampang also come home for performing mang wherever they live and work for earning livelihood. Those moves are known as different terms like, mang garna jane/pitra garna jane and nwagi garna jane in Rai community. These types of moves have central values in Rai community. Such kinds of mobility are associated with a calendar of annual indigenous social/ religious and ceremonial events which are also identified by Memmott, Long, Bell, Taylor \& Brown (2004) as well.

The terms, Tirtha yatra garne (moves as pilgrimage), Char dham jane (pilgrimage to four main Hindu shrines), Shradha garna jane (moves for ancestral praying), Astu selauna jane (moves for religious purpose), are especially related to Brahmin/Chhetri community. Such moves are characterized by single and several visits of religious places, temples, shrines in a group or individually within country, and beyond. People visit Chardham for getting psychological satisfaction, purification, and performing moral obligation to earlier generation (Subedi, 1993). Its main goal is attaining salvation after death as per the assumption of Hindu philosophy. Generally, the elder persons are participated in those activities. Rai community is not associated with Hindu religion, so the people of this community do not get involved in such kind of visits. But in the recent days, some people of Rai community even participate as the result of influence of Aryan culture and Hindu religion on other ethnic communities in Nepal (see, Rai 2017).

\section{Moves related to economic purpose}

All the moves, related to economic activities for livelihoods of the household, include economic movement which is in increasing trend at present (Table 1). Basically, the household economy was self-dependent type based on agriculture in the past but it is going to be dependent. The terms - such as kulli bharti jane (moves for porter 
and labor), aara katna jane (moves for sawing timber), bhari bokna jane (moves for carrying loads as porters), suntala/alainchi bechna jane (moves for selling orange and cardamom), paisa lina jane (moves for taking money from financial institutions), rin tirna/uthauna jane (moves for paying off and taking money back) and kamauna jane (moves for earning) are included in economic moves. The mobility motivated by economic activities was not so higher than other movements in the past. However, it is expanding day by day due to the influences of globalization and a decreasing position of self-depended economic activities of the household. Of course, it is also more visible than other moves.

Kulli bharti jane (wage labor migration), koila khani jane (move for working at coal mine) and aara katna jane (move for sawing) also include the regular territorial mobility for earning livelihood in Nepalese villages. The people in the rural areas had limited sources of cash income as well as inadequate sources of livelihood in the past. Hence, people were compelled to migrate to India for earning cash and sustaining their households (IOM, 2019). Those opportunities opened while the construction works and resource extraction were common during British India rule in India (Subedi, 1993). Being involved in kulli bharti, koila khand and aara katna jane are not only matter of compulsion; those are also related to the desire for a visit beyond and refreshment purpose in a leisure period, especially in the winter. The term bagada khana jane (move for rice meal) was also used for those whole activities. This context indicates the scarcity of rice meal in the hilly region in the past. The proverb desh pani herine mukh pani pherine refers to the strong intention of movers for getting chance taste new food items and entertainment. This saying is very popular in Nepalese society, especially in the hilly region for visiting outside of home. The risk of movers in the new place and new works is also represented by this popular progressive song: aara katna bhani gako mero jetha dai, rukha dhali kichi maryo suna sathibhai. This song is loosely translated this way: The elder brother of someone had gone for sawing a timber but died due to the falling of a tree upon him in the distant land. Movers were badly affected by several events, such as death, injuries and sickness frequently in the alien land. The painful situation of movers to Muglan is portrayed nicely in the novel Muglan by Bhattarai (2031). The pithy saying, prevalent in the village, bagada khana gaako, langada bhayara aako also refers to the vulnerable condition of life in pardesh (distant land) and a real picture of Nepalese society from the very beginning till now.

Khelo phadko garne (engage in small business for earning) has become an important economic activity as the result of the increasing transportation facility, growing interest towards earning cash, beginning of cash crop farming, and the establishment of market center in the village which are recently amplified as territorial mobility especially in 
rural areas of Nepal. Khelo phadko garne means a petty business that needs no large investment. Local small vendors are involved in this activity in their leisure time the season from harvesting orange, cardamom, and rudraksha (eloecarpus sphericus) collection. Agricultural products are taken to the market by such small businessmen through collecting them from farmers. Manufactured goods are bought in the wholesale market and resold by the local businessmen in the local market. Some of the vendors collect piglets, chickens, chicken eggs, goats, grains and vegetables and sell in the weekly market (bazar) by taking some profits. A short excerpt from a conversation with a local small businessman Mr. K. Ramtel (aged 28 years) is as follows:

In the season, I purchase orange from the tree in the village and sometimes purchase whole orange tree in the season. Then, I take them to Tumlingtar and sometimes to Khadbari. Sometimes, I take goats and chickens to the market by collecting them from the village for earning profit. There are others friends like me who are also involved in petty business of fruits, vegetables and grains and some in merchandise goods. Some local businessmen are involved in the business of cardamom and rudrakshya (eloecarpus sphericus) or dana (in local term) at a large scale. They take their goods to Dharan by loading them in the mini truck. Vendor is our part time and a seasonal job for sustaining livelihoods.

Now-a-days, the work, paisa lina jane (taking money) has become a prominent mobility in the rural areas of Nepal. The other terms, such as bank jane (move to bank) and IME jane (move to IME), are also used for paisa lina jane in local term. In the later days, foreign employers send money through IME and Bank located mostly in the district headquarter and regional market centers. It needs whole single day or more for commuting. A large number of households are depended upon remittances for their livelihood in the rural areas of Nepal. It has become a main basis of Nepalese economy. Daily transaction of an IME located in Tumlingtar also shows the over increasing role of remittance in the rural areas, which also hints at more mobility of people between village and district headquarters and regional market centers. An IME proprietor informed that about one hundred people come daily for remittance purpose in Tumlingtar. A widespread movement in the rural areas, especially in Rai community of ex-Lahures families, is pension lina jane (movement for taking pension from Welfare Centre and Soldier Board). They used to go to Purnia of Bihar state of India in the distant past for this purpose. But now in the case of Sampang, ex-Lahures of British and India visit Welfare Centre and Soldier Board for taking pension located in district headquarters of 
Bhojpur. Nowadays, taking time distance to bank and IME has been decreased due to construction of local roads and establishment of banks and IME offices (see, Rai 2017).

Rin pan (money borrowing and lending) was a very common phenomena in the past for sustaining a practical rural life because there were no formal financial institutions and organizations like banks and finances. Most of the common people living in the rural areas used to depend on sahu mahajan (local money lenders) for loan. So, the terms rin tirna jane and rin uthauna jane (paying and taking money) were common activities related with mobility. Local landlords and money lenders used to invest money not only in the village but also in neighboring village and distance apart. However, the mobility within village related with rin pan has decreased in the recent days.

Bhari bokna jane (move for carrying loads) as a porter, is a kind of mobility driven by for their livelihood sustaining in the rural areas of Majhkirant when the road transportations were not available in the hilly region. Merchandised goods were brought from Dharan to eastern hill and mountain districts by only one of the means. It took ten to twenty days to carry loads. A large number of poor people's livelihood in this area was made as porters. Life seemed very painful when one sees them as a caravan with heavy load with not such feeling in their real life. This reality is proved by expressing their views this way: dhakreko jiban ek sok, ek bhog (porters' life without pain and strain). Some of the households had lived on portering as a side job and some as a main occupation. Kattel (2000) has explained the clear picture of the portering occupation by Kumal community of Tumlingtar of Arun valley.

\section{Moves related to political and administrative activities}

There are different moves related with political activities such as baithakma jane (moving for meeting), aamsabhama jane (journey for mass meeting), delegation jane (moves for delegation), prasikshanma jane (move for instructions), chunab pracharma jane (moves for election campaigning), bhumigat hune (move for political activities as underground), and bhot dina jane (move for casting vote). Such types of mobility have excessively increased after the restoration of democracy in Nepal (see, Rai 2017). The first four moves are directly related to committed politicians who are always engaged in politics. Those all mobility are mainly centralized in the district headquarters. The term bhumigat hune became prevalent when CPN (Maoist) started an armed rebel in 1995 and in Panchayat period as well. This territorial mobility is uncertain in terms of duration of mobility and a range of distance. A young person, B. Rai of 32, expressed his experience of bhumigat jiban (underground life) in this way: 
I got involved in Maoist party in 1995 and became bhumigat from that time. First of all, I took training in Sindhuli and we controlled police post of Sindhuli in April, 1995. It was my first experience of an armed war. I was arrested in 1996 in Boya and held captive for one month in police custody. After being bailed, I stayed in the village for some time. The contact with party was maintained and again, I became underground. We did action in various police post and district headquarters as well. We achieved success in most of the wars. After lokatantra (people's democracy), I returned home appointed as a district committee member (DCM) of the party but now I am DCM of NCP (Maoist/Vaidya).

About a dozen of youth participated in People's Liberation Army (PLA) in the conflict period from Sampang. Among them, most involved in open politics and frequently move to the district headquarters and regional market centers as political activist. Some moves as party cadres such as; meetingma jane (move for meeting), delegation jane (move for delegation), amsabhama jane (move for mass meeting), prasikshanma jane (participation in instruction) and andolan garna jane (move for agitation) are common phenomena in this area. Bhot dina jane (move for vote casting) is also a political move of mass population within village in a democratic system but it appears occasionally within five years.

Citizenship certificate is compulsory to every citizen of Nepal. It is necessary to show citizenship certificate to prove a national identity in any formal occasion. So, people go to District Administration Office to obtain the citizenship certificate. In the same way, the people who would like to go to foreign countries need to obtain passport. These both types of works involves travels of rural residents as obligatory type of territorial mobility. These phenomena have been increased recently while the trends of labor migration and abroad studies have been increased in rural areas of Nepal. Such kind of move is called nagarikta banauna jane and passport banauna jane (move for getting citizenship and passport) in Nepalese terms. Bill tirna jane (moves for paying bill) is a kind of regular moves of rural people in monthly basis to the electricity office. Electrification has been done in rural areas without expanding branch office of Nepal Electricity Authority (NEA) for paying bill. So, rural people need to walk a long distance for billing there. People of Sampang go to Tumlingtar branch office to pay electricity bill on a regular basis in each month. People move to Tumlingtar not only for single reason but also for multiple purposes including purchasing something for the household. When movement occurs for Tumlingtar by multiple reasons, it is called Tumlingtar jane in local term. 


\section{Moves related to livelihood and occupation}

The terms - such as Lahur jane (moves for recruiting British-Gorkha Army), Arab jane (moves to Gulf country for labor migration), bidesh jane (moves for foreign employment), jagir khana jane (moves for professional service) are related with livelihood and occupational movement. Lahur jane is a popular move among Rai community of Sampang. In other words, such as Bharti jane and Paltan jane are also used for this move. It is also age specific, eighteen to twenty one, and gender specific limited in male. The words "Lahur jane" were frequently uttered in this community. Blessing was given by elders to sons to be Lahure and to daughters to be Lahureni (wife of Lahure), especially during wish making occasions. It was the matter of grief when somebody gets hurt and spot in the face as well as fracturing of hand and leg in small age, not able to be Lahure in the future. The importance of Lahure was clearly reflected by the question raised to the candidate of groom in this community during putting marriage proposal with parents, especially in an arranged marriage: Lahure ki chaure (either Lahure or other). The saying, like padhilekhi ke kam, Lahure bhaya damaidaam (Lahure earns money more than what an educated person earns), also indicates the priority towards Lahure in Rai community for earning money (see, Rai 2017). The status of British Lahure was higher than Indian one. British-India recruited only certain Nepalese ethnic group, Rai and Limbu in the eastern Nepal and Magar and Gurung in the western from $1815 / 16$ AD. The reason for recruiting only a certain group is still unclear. Good health and attractive physique were the prerequisites for recruiting army. A British Lahure gets a leave in every three years for three months. Family (spouse and kids) also can go with Lahure after first leave. The word Paltan jane (move to Platoon with husband) is used for family context too. Recruitment was done in a large number till two decade ago. But the number has declined recently by a curtailing policy of the British government on Gurkhas. The criteria of recruitment have also changed: emphasis on education over body that has become a difficult task for youths living in the village recruiting in British army. However, the situation was totally different in the past. In the contrary, young boys were taken for recruitment forcefully if not convinced easily in the period of the world war, first and second.

The social prestige and dignity of Lahure was great in Rai community. Not only Rai community, this tendency is commonly found in other Mangolian community like Gurung which is reflected in Gurung (2011) research. Since every parents had a sweet dream of making Lahure to their sons and making Lahureni to their daughters. The practice of different items, such as hanging, pull up, set-up, and running for the exercise of Lahure recruitment, starts after getting fifteen years. The desire to become Lahure was great. Earlier, Ghumpahad Kuna of India was the place of recruitment for British- 
Gurkha regiment. Many youths moved to Ghumpahad Kuna for recruiting Lahure in the past. The folk song, sung especially by the youths in the village such as salko pat duna, kun bato jane Gumpahad kuna, also vividly shows their strong desire and goal to become a Lahure in their life.

However, Lahures' life always remains in uncertain and critical situation as well in the foreign land though they have sweet imagination of meeting in the future with family and friends. The song, chiththi aayo dhagole bandhera ..., also gives the real meaning of the risky life of Lahures. It is also said that Lahureko jiban khukuriko dhaarma means Lahures' life is teetering on the edge of khukuri (sharp weapon). The war between Argentina and British in the history, a war in Falkland Island together with India and Pakistan, and a war in Kashmir also remind one of an uncertain situation of Lahure's life. Similarly, ex-Lahures are known as very experienced in different practical knowledge and skills they learn in the foreign countries during the service period (see, Rai 2017). The village gets various benefits directly and indirectly from sharing such skill and knowledge. So, the life of ex-Lahures is accepted as a suitable example of this proverb in the village: desh khai ses bhayako.

The term bidesh jane (move to foreign land) has become widespread in Nepalese society in these days. Due to lack of employment and different kinds of opportunities, most of the youths have been moving towards foreign land like Gulf countries (Saudi Arab, Qatar, Kuwait, UAE) and Malaysia as foreign migrant workers. The tendency of women migration has also increased as a domestic labor but it is still male dominated (IOM, 2019). The word Arab jane is also used easily by common people in the village. The term new Lahure is also found in some literature. However, the term Arabe Lahure (Lahure of Arab) is also used locally for the persons who move to Arab countries. The term Dori Lahure is also heard elsewhere for foreign employees. This term is related to them considering wrapping style of their baggage by ropes while coming from Arab and Malaysia. Their real situation is not so good due to low salary and an unfavorable climatic condition of destination places for Nepalese migrant workers. Likewise, a lot of events of family break are found in the case of Arabe Lahure in the rural community including Sampang. So, the saying Arab ki dharap (Arab as a danger place) is becoming popular in the mouth of the villagers. The report of IOM further states that;

Nepal's low-skilled migrant workers are also subject to dangerous working conditions and poor living and working conditions, increasing their risk of work-place accidents. Poor living and working conditions can also lead to the spread of infectious diseases. Women migrant workers are particularly at risk of physical and sexual abuse, particularly those who have been trafficked. (p. 99) 
Nevertheless, this activity has become both compulsive and fashionable among the Nepalese youths. Beside gulf countries and Malaysia, the Nepalese youths' visit South Korea as a labor migrant is regarded as an attractive destination due to high salary.

Table 2: Caste/ethnic dimension of territorial mobility

\begin{tabular}{|l|l|l|}
\hline \multirow{2}{*}{$\begin{array}{l}\text { Category of } \\
\text { moves }\end{array}$} & \multicolumn{1}{|c|}{ Caste/ethnic based moves } \\
\cline { 2 - 3 } Socio-cultural & $\begin{array}{l}|c| \\
\text { Kaliya jane, Koseli liyara jane, } \\
\text { Maganima jane, Pasnima jane, } \\
\text { Chhewarma jane, Nwaranma jane, } \\
\text { Panchawalima jane }\end{array}$ & $\begin{array}{l}\text { Puranma jane, katha sunna jane, } \\
\text { Saptahama jane, Kanyartha jane, } \\
\text { Barakhima jane, Bratabandhama } \\
\text { jane, cheli lina jane }\end{array}$ \\
\hline Religious & $\begin{array}{l}\text { Pitri/Mang garna jane/Nwagi garna } \\
\text { jane }\end{array}$ & $\begin{array}{l}\text { Tirthayatra garne, Chardham jane, } \\
\text { Deudham jane, Pashupati darsan } \\
\text { garna jane, Astu selauna jane }\end{array}$ \\
\hline Professional & $\begin{array}{l}\text { Lahur jane/Paltan jane/Bharti jane, } \\
\text { aara katna jane, }\end{array}$ & $\begin{array}{l}\text { Puran/Puja launa jane, Paath garna } \\
\text { jane, Jagir khana jane }\end{array}$ \\
\hline $\begin{array}{l}\text { Recreation/ } \\
\text { entertainment }\end{array}$ & $\begin{array}{l}\text { Sikar garna jane, machha marna jane, } \\
\text { juwa/tash khelna jane, nachna jane, } \\
\text { khelna jane }\end{array}$ & $\begin{array}{l}\text { Mela bharna/herna jane, Jatra herna } \\
\text { jane }\end{array}$ \\
\hline
\end{tabular}

Source: Field survey, 2014 and 2019

Jagir (government service) makes a person more mobile because of its transferable nature. Furthermore, jagir is usually not available in the home territory. One should leave home to get a government service. The old but popular proverb-uttam kheti, madhyam byapar and adham jagir (best farming, medium business and worst service) - also carries the meaning of low preference for government services. Despite such condition in the past, the recent notion has totally changed in the society. So, participation and attraction in jagir varies on the basis of Nepalese society. The importance of jagir is great in Brahmin/Chhetri society from very beginning due to their access to education. The tendency towards jagir has been developed as culture. Therefore, education attainment is a prerequisite for jagir. It is called white collar job. Jagir is not only money (salary), it is also power, prestige, and access to different sectors and levels of state. Therefore, this generation is interested to move a long distance in inaccessible and remote areas of the country for government job. Comparatively, this move is male dominated still now because of low participation of women in this sector. This context matches with ethnic community including Rai of Sampang. But recently, the situation is in increasing trend after commencement of reservation system in Nepal for the government service. A certain age group may be eligible for government service. Such kinds of movers are generally adults, such as those aged 20 to 60 years. 
All kinds of moves motivated by economic purpose comprise several kinds of mobility. Such mobility is directly related with occupation. Most of the occupations in the past were based on caste and ethnicity. So, the prevalent moves - such as siuna jane (walk for sewing), bajauna jane (walk for playing musical instrument), saan launa jane (walk for sharpening weapons), puja launa jane (walk for praying), phukna jane (walk for healing), and ghar banauna jane (move for constructing house) comprise those territorial mobility mostly based on a traditional occupation in the rural area (Table 2). The first three moves (siuna jane, bajauna jane and saan launa jane) are related to Dalit castes within short distance for short period. Those phenomena were more common in the past. Over the time, these movements are declining due to the fall in the caste based occupation. The term puja launa jane is also a short term movement related to a ritual work for Brahmin society in which purohit (Brahmin priest) participates. The moves, phukna jane, is also common in rural community (see, Rai 2017). This was widespread in the past when there were no medical facilities for treatment in the rural areas and common people were dependent completely on local healer. The term ghar banauna jane is also a local movement of skilful people within village and market centers for some days and weeks. Basically, such types of moves occur in winter and agriculture off-season. Similarly, majdurima jane (labor work) has become extensive in the recent days as the result of increasing local development works especially road construction and government building such as school, hospital, rural municipality office etc. after commencement of federalism in Nepal. Various reconstruction works in the rural areas are also associated with Gorkha earthquake- 2015.

\section{Moves related to educational and skill development}

Moving for getting education is called padhna jane (moves for study) in a customary sense. The system of education was maintained in gurukul (traditional system of education) in the beginning. Relation of education was directly associated with religious and cultural context. So, it was primarily confined to religious teaching and text only for men of Brahmin families. In other words, it was felt that education was necessary for the sons of Brahmin to perform religious and cultural activities which are based on Sanskrit text. Brahmin people used to go to Banaras of India for taking education because there were no facilities for education in the village. Therefore, the term Banarash jane is also used for the moves padhna jane especially in the Brahmin community. The name and fame of Banaras was great for obtaining Sanskrit education in India including Nepalese people. Some Brahmins sons moved there for education by escaping homes if they were not allowed by parents. They returned home after taking education up to purba madhyama (equivalent to SLC), uttar madhyama (equivalent to proficiency certificate level), shastri (equivalent to Bachelors level), and up to aacharya (equivalent to Master's Level). 
Subedi (1993) discussed the mobility related to padhna jane especially Sanskrit education in India. However, the sphere and importance of education has recently increased excessively. So, the mobility pertaining to education appears in different forms within local, national, and global level. The value of education has changed. It has become essential things for making a living. Occupations are determined by the quality of education. Education attainment is not only limited to certain sex, caste/ethnicity, and region. Educational institutions related to the school level are established in the village but there are no institutions on higher education till now. So, people should move elsewhere in city area for higher education. So today, many terms are associated with educational moves in the society: padhna jane/adhyanma jane (move for study), ketaketi padhauna jane (move for children's education), campus jane/college jane (move for higher education), janch dina jane, (move for taking examination) and kharcha puryauna jane (carrying logistics to children), and so on. The mover going somewhere beyond the village for any kind of education is called padhna jane and adhyanma jane, which are recently known as campus jane or college jane. The person returns homes after getting two to four years of education. In the present days, the attractions towards private boarding schools have been increased in the rural areas but are not available there in Sampang. Therefore, some people keeps their children with guardians (mostly with mother) in the district headquarters and other urban centers where boarding schools are established. Such moves associated with children's education are called ketaketi padhauna jane and kharcha puryauna jane in local terms. So, the mobility has been increased in the rural areas with the purpose of educational activities (Table 1). The role of international remittance is great as major motivational factor for investing in quality education of both son and daughter in the rural area of Nepal (see IOM, 2019).

The dimension of education has now been changed drastically in the Nepalese society. Higher education is not bounded within national boundary. A large number of Nepalese youths are also moving as student to foreign countries including India every year. Basically, girls move India for taking technical education especially nursing. Those kinds of moves are called adhyan garna jane or bidesh padhna jane in Nepalese terms. A large numbers of young people disappear in abroad for the purpose of higher education and very small portion return back in the country. This trend is on the rise. It has become a sweet dream of Nepalese youths getting visa of America, Australia, Europe and so on. Not only study purpose, but also Nepalese youths move to America for settling down there after getting PR and TR visa. Diversity visa (DV) system has become a process for entering America to Nepalese people. 


\section{Moves for recreation or entertainment}

In addition to religious importance, mela and jatra provide great opportunities to maintain social relation, to make a social network, and to choose marriage partners for taruni (teenage girl) and tanneri (teenage boy), as expressed pithy saying-jaun bazar paisako nash/kharab, najaun bazar taruniko aash/shrap (if I go to bazar money is wasted; if not, beautiful girls are missed)—and a popular folk song-ekadashi bajaraima phanke roti thalma, kasko chhora kaski chhori paryo maya jalma (in Ekadashi bazar, round bread is served on the plate; unfamiliar boys and girls fall in love at the first meeting). The popular mela — such as Balachaturdashi and Ramnawami Mela of Dingla, Ekadashi Mela of Manakamana, Dabali Mela of Bhojpur and Pakhuwa Mela of Tintale - are famous for a good place for love partners to make their love a success in their marriage in this area. The mela and jatra in Rai community is taken as enjoyment and entertainment for leisure period in rural life. Such types of event is found in aboriginal mobility patterns of Central Australia which is illustrated in the research of Memmott, Long, Bell, Taylor \& Brown (2004). Singing and dancing activities with drinks are a common phenomena of such melas in this Majhkirant region. Dohori geet, such as Hakpare (folk song especially sung in Arun Valley), used to sing songs continuously till seven days and nights between tanneri (young boy) and taruni (young girl) sitting under the bar-pipal tree (Chautara is the resting platform). Many boys and girls fall in love and some get married by putting a witness to bar-pipal tree. Most of the participants in such kinds of recreational activities were related to the young boys and girls of Rai community especially in winter season. Various moves - such as khel khelna jane (moves for playing), sikar garna jane (moves for hunting), machha marna jane (moves for fishing) and nachna/gauna jane (moves for dancing and singing), and so on-are some of the important ones relating to youths' entertainment in the rural areas, especially in Rai community of Majhkirant including Sampang (Table 2). In the latter days, such moves as entertainment are in declining trend (Table 1).

\section{Moves based on obligation and reciprocal relationship}

The obligatory move is an important territorial mobility in the rural as well as in urban areas because it is associated with state rule and regulation over the people by the government. It is also connected with facilities and services provided by the government to people. In the past, jhara tirna jane (movement to compulsory labor) especially during the Rana rule in Nepal, used to forcefull participation of people in developmental activities such as road, buildings, temple, and canal construction etc. People even used to move one or two days of walk from home for jhara tirna by carrying khaja-samal (foodstuffs). However, after the dawn of democracy in Nepal such types of moves disappeared. 
The terms adda jane (move to government office) concerning to territorial mobility is common in rural society. In the society, a statement Ja pachhi Jha aaunchha is very popular. It has a symbolic meaning, or it means that jagga liyapachhi jhagada suru hunchha (dispute starts after land purchasing). The social and economic value of land, as being a major property of a household, was very high in the past. For this reason, cases (disputes) were more likely to arise during and after the land purchasing process get completed. There were many cases in the court related land and this situation is still now to some extent. Therefore, moving to court, also an important work of people residing in rural areas, is called adda adalat jane. The next important move, related to land is called rakam bujhauna jane/tirna jane (to pay land tax) and mal adda jane (move to land revenue office). Jagga paas garna jane (move for land registration) and naamsaari garna jane (move for land ownership change) are also associated with jagga-jamin (land i.e. farming land). Most of the movements relate to adda jane were related with land in the past however, decreased in the present time due to the decrease in land transaction in the villages.

\section{Moves based on kinship and neighborhood network}

The short-period of moves based on kinship and neighborhood network are maita jane (move to natal home), janta jane (to participate in a marriage ceremony), kanyartha jane (movement for seeking bride), kadkal jane (move for escorting), rit puryauna jane (move for bringing articles in marriage), nimto manna jane (movement for participating in social events), birami herna jane (movement for meeting sick person), birami liyera jane (movement for bringing sick person), saghauna jane (moving for helping), parma tirna jane (moving for labor exchange), kaliya jane (participate as mediator in marriage ceremony), maganima jane (movement for seeking bride), and nwaranma jane (participating in name giving ceremony). Such types of moves help keeping neighborhood linkages and inter-household relationships as well as maintaining a kinship relation in the rural communities. These types of moves are even mentioned by Young and Doohan (1989) in relation to the aboriginals of Central Australia. However, the above mentioned moves are not common in all caste and ethnic groups, nor do in all age group and sex. The moves - such as rit puryauna jane, maganima jane, kaliya jane, and nwaranma jane and so on - are related especially to Rai community (see, Rai 2017). Of them, the former three (rit puryauna jane, maganima jane and kaliya jane) are concerned with the marriage ceremony and the last one (nwaranma jane) with namegiving ceremony, respectively. Kanyartha jane (movement to seek bride) is mainly used by Brahmin-Chhetri community as parallel terms maganima jane of Rai community (Table 1). The rest of the other words used for short-term movement often belong to all castes and ethnicities. But the two items, saghauna jane (moves for helping) and parma 
tirna jane (moves for labor exchange), mainly prevail in Rai community residing in this Sampang area because these practices are more common for this community from very beginning. Mostly, senior persons or the family heads are involved in the moves such as birami herna jane (moves for meeting sick person), kanyartha jane, and kaliya jane etc.

\section{Moves based on daily necessities}

Most of the moves based on daily necessities for rural life cover short period of time and short distance. The major types of territorial mobility based on daily necessities in the rural areas of Majhkirant region are bazar jane (move for marketing), sauda garna jane (move for purchasing), aspatal jane (move for treatment), bijuwama phukna jane (move for healing to shaman), mal lina jane (move for bringing chemical fertilizer), tel pelna jane (move for making oil in the mill), bill tirna jane (walking for paying bill), and phone garna jane (walking for phone), and gai/goru/bhaisi/khasi/sungur kinna jane (walking for purchasing animals) etc.

Most of the consumers of the urban areas are dependent on the market for their daily necessary goods and services. This trend has also been increasing day by day in the rural areas due to the changing pattern of consumer behavior (see Koirala, 2006) and even major activities of the people living in the rural areas. The term, bazar jane includes various types of marketing activities for different purposes in the rural community. Sauda garna jane and saman kinna jane terms are also used for this purpose.

The next prominent move of the rural people in this region is aspatal jane (walking to hospital for medical treatment) that has been common types of territorial mobility. Upachar garna jane and ausadhi garna jane are some synonymous words used for this mobility. However, dhamima phukna jane and bijuwalai dekhauna jane (consult witch doctor) were the terms more prevalent in the past. Now-a-days, people of Sampang area visit health posts located in the village in normal case and go to Tumlingtar, Dharan, Biratnagar, and Kathmandu for serious cases of medical treatment.

As agriculture is the main occupation of rural livelihoods in Nepal, the practice of purchasing chemical fertilizer (bikashe mal) from the district headquarter or regional market center is known as mal lina jane in Nepalese terms. Such move is more apparent especially at the beginning of two seasons - summer and winter of the year. Tel pelna jane (crushing oilseed in mill) is also a short time and short-distanced mobility connected to seasonal cycles after immediate harvesting of mustard seed and the beginning of main festival. 
Hulak jane/chiththi pathauna jane (moves for sending letters in post-office) and phone garna jane are also local types of short time and short-distanced movement to exchange information with family members living outside home. However, the mail exchange through post-office has been replaced due to increasing access to landline phone and cell phone nowadays.

The moves related to buying or purchasing of cattle, buffalos, goats, and pigs are also important territorial mobility in the rural areas of Majhkirant region. The transaction of such kinds of livestock takes place in the village for meat, milk, and ploughing oxen. Basically, Rai people search pigs and buffaloes for meat on the occasion of festivals and wedding ceremonies, mostly in the winter season which is known as leisure period. Similarly, Brahmin people seek goats, milky cows and buffaloes for meat and milk. Somebody moves out of village and spends more than one day for such purpose.

\section{Baralina jane (Walk about)}

Baralina jane refers to walking rudderless (walkabouts). This type of territorial mobility includes ramit herna jane (visit for sightseeing), sathi bhetna jane (move for meeting mate), parcel puryauna jane (move for handing over gift), nachna jane (move for dancing), khelna jane (move for playing), juwaltas khelna jane (move for gambling). The last one juwa/tas khelna jane was very noticeable in the past. Those types of moves are often confined to younger age in male group. This tendency is mostly found in Rai community of young age, called allare umer (teen age). However, baralina jane (in the sense of time killing) is neither taken as a positive aspect nor does it have any certain destination and any achievement. Ramit herna jane (move for taking enjoyment) is concerned to recreational activities after long busy work as well as in winter season in the rural areas. Similarly, youths of the village sometime participate in volleyball and football match organized by local clubs and different organizations and Sakela naach (Sakela dance) in the neighboring village. The range of duration and distance of baralina jane moves remains uncertain in such territorial mobility in rural community. Parcel puryauna jane (visit for passing goods) and saathi bhetna jane (visit to meet friend) also belong to Lahures and Arabe Lahures who come home on leave and participate in such moves. These kinds of moves (walkabouts) are common especially in Rai community of Sampang.

\section{Gaun-bensi garne (Transhumance)}

The term gaun-bensi garne or lek-bensi garne (moving highland and low land) is a seasonal movement in the upper and lower part of the hill is also known as transhumance system in the whole hill region of Nepal. It is a back and forth movement of households 
with their livestock within a considerable distance between two places. The purpose of movement is to rear livestock along with agriculture. It is common to spend six months in lek (upper land) and bensi (lower land) with livestock as well as performing agriculture activities. These regular activities of rural people are always determined by the seasonal cycles.

\section{Ghar phirne (back home)}

Ghar phirne (returning home), an important component of ghumphir (short-term mobility) refers to returning home by absent members of the family to fulfill obligation and commitment towards household members, kin network, neighbors, and relatives. Ghar phirne (back home) is known as the important duty of movers. Most of the absent members come back home, especially in the festival, ritual works, and traditional ceremonies in the rural community.

Mobility patterns of people living in any place are also influenced by seasonal events. The calendar is determined on the basis of a climatic condition of a place (Smith, 2004). Most of the customary and ritual activities belong to different communities and are directly and indirectly related with seasonal calendar. Seasonal calendar includes events from busy life to leisure type of life pertaining to entertainment and recreational activities. Mostly, the people of agrarian society in rural areas of Nepal move outside home for different purposes especially in the winter season due to the leisure period in this season. This context is more suitable in the case of married women. This pithy saying always uttered in this area also covers these circumstances: paiyou phul phuldaa maiti ghar samjhanu, aaru phul phulda aaphnu ghar samjhanu. This saying indicates the two suitable seasons for meeting and taking enjoyment and being busy for agricultural works, such as taking enjoyment in winter from aaru (peach) flowering and from paiyu (prunus cerasoides) flowering and engaging in work in summer. The findings of Smith (2004) also have shown clear seasonal patterns of mobility in Cape York, especially in the dry and wet season.

The beginning of the agricultural season and harvesting period are the prime factor for returning home by movers from beyond in the rural community. The household head, especially man, returns home in the sowing periods for ploughing which was a mandatory work related solely to man. However, this situation has now been changed where people have started to focus for cash crops such as orange, cardamom, and rudrakshya etc. Similarly, woman also started ploughing in the fields which were not common in the past. 


\section{Conclusion}

Territorial mobility is not only part of survival and common feature of rural living it also reflects whole life style and life pattern of the community. Therefore, caste ethnic dimension of territorial mobility is an important aspect of traditional community of rural area. Basically, there are two forms of mobility: basai sarai and ghumphir in the rural context. Basai sarai includes those forms of mobility that primarily involve permanent relocation of households and individuals from the place of origin to another destination place. Ghumphir is the people's movement within short distance and short period of time for different purposes. The nature of ghumphir varies on the basis of caste and ethnicities in the rural context. The people of Sampang have been participating in various forms of mobility for their daily livelihood from the very beginning. Their movements are not only confined within home territories but also to foreign countries as Lahur jane (Gurkha recruit) and recent labor recruits as wage workers particularly in Gulf countries and Malaysia.

Mobility in the eastern hills of Nepal have many similarities as the forms and types are the same when compared with studies accrued out more than two decade ago (see, Subedi 2000). However, in the case of Manjhkirant the tendency to lahur jane or paltan jane, naach gaan ma jane, koila khani jane, ketaketi padauna jane, sikar jane, pitri garna jane appeared more common. This example also signifies that the nature and degree of different kinds of moves differs according to space and time. These variations reflect the socio-cultural, religious, and economic difference in Sampang as this area is predominantly settled by Rai community and is part of Majhkirant. Over time some types of moves have expanded, while others have disappeared. Likewise, some moves have taken modified form and some have continued in their original form. Furthermore, the moves related with economic, political, professional, educational and awareness, have become more extensive and common than ever before.

\section{References}

Acharya, B. (1968). Shree Panch Badamaharajdhiraj Prithvinarayan shahko sankshipta jibani [A short biography of His Majesty Pirthvinarayan Shah]. Kathmandu: Chief Press Secretariat of His Majesty.

Alexiades, M. N. (2009). Mobility and migration in indigenous Amazonia: Contemporary ethnoecological perspectives. New York: Berghahn Books.

Bangdel, L. S. (1948). Muluk bahira [Beyond the country]. Kathmandu: Ratna Pustak Bhandar. 
Dhyanendra, Bhim, Hriday Lal/ Territorial mobility ...Vol. 14: 81-112, 2021

Bell, M. and Ward, G. (1998). Patterns of temporary mobility in Australia: Evidence from the 1991 Census. Australian Geographical Studies, 36 (1): 58-81.

Bhattarai, G. R. (1974). Mugalan [Abroad]. Kathmandu: Oriental Publication.

Cresswell, T. (2006). On the move: Mobility in the modern Western world. New York: Routledge.

Gurung S. (2011). British Gurkha recruitment and higher education of Gurung young men. Dhaulagiri Journal of Sociology and Anthropology, 5: 143144.

Heide, S. V. (2001). Some aspects of migration, mobility and the democratic movement among the Thkalis: Effects of cultural change and the danger of cultural change and the danger of cultural loss. In S. V. Heide, \& T. Hoffman (Eds.). Aspects of migration and mobility in Nepal. Kathmandu: Ratna Pustak Bhandar.

HMG (2032 B.S.). Divyopadesh: An enlightening sermon, Kathmandu: His Majesty's Government of Nepal.

IOM (2019). Migration in Nepal: A country profile- 2019. Kathmandu: International organization for migration (IOM).

Kansakar, V. B. S. (1974). History of population migration in Nepal. The Himalayan Review, VI: 58-68.

Kansakar, V. B. S. (2005). International migration in Nepal for livelihood. B. P. Subedi \& P. C. Poudel (Eds.).Geography and geographers' work in Nepal: Reflection on mountain environment and human activities. CDG, NGS and NCCR.

Chhetri, L. B. (1957). Basain [Migration]. Lalitpur: Sajha Prakashan.

Kattel, S. P. (2000). Development and its victims (From pottery makers to porters: The changing life world of the Kumals of the Arun Valley, Eastern Nepal) (Unpublished M. Phil Thesis). University of Bergen, Department of Social Anthropology, Bergen, Norway.

Kelly, R. L. (1992). Mobility/sedentism: Concepts, archaeological measures, and effects. Annual Review of Anthropology, 21: 43-66.

Koirala, H. L. (2007). Livelihood pattern, adaptive strategy and sustainability of communities in Southern Arun Valley of Nepal Himalayas. Unpublished PhD Dissertation. Gauhati University, India.

Lemos, A. (2010). Post-mass media functions, locative media, and informational territories: New ways of thinking about territory, place, and mobility in contemporary society. Space and Culture http://sac.sagepub.com/ content/13/4/403: DOI: 10.1177/1206331210374144 2010 13: 403 
Memmott, P., Long, S., Bell, M., Taylor J. \& Brown, D. (2004). Between places: Indigenous mobility in remote and rural Australia. Aboriginal environments research centre, and Queensland centre for population research. Paper presented at the annual meeting of University of Queensland, Autralia.

Rai, D. B. (2017). Sense of place and its reflection on territorial mobility in Rai community of Sampang village of Majhkirant. (Ph.D Dissertation), Faculty of Humanities and Social Science, Tribhuvan University.

Rai, K. J. (2074 BS) [2017]. Sakkhewa sily- ek adhyan [Sakkhewa method-a study]. Lalitpur: Aadibasi Janajati Uththan Rastriya pratisthan.

Shah, P. N. (2032 B.S.). Divyopadesh: An enlightening sermon, Kathmandu: His Majesty's Government of Nepal.

Sheller, M., \& Urry, J. (2006). The new mobilities paradigm. Environment and Planning, 38: 207-226.

Sirkeci, I. and Cohen, H. J. (2016). Cultures of migration and conflict in contemporary human mobility in Turkey. European Review, 24 (3): 381 - 396 DOI: 10.1017/ S1062798716000119.

Smith, B. R. (2004). The social underpinnings of an outstation movement in Cape York Peninsula, Australia. In Taylor, J. \& Bell, M. (Eds). Population Mobility and Indigenous Peoples in Australasia and North America. London: Routledge, 239-261.

Subedi, B. P. (1993). Continuity and change in population movement: From inside a rural Nepali community (Ph.D. dissertation). University of Hawaii, Department of Geography.

Subedi, B. P. (2000). Conceptualizing territorial mobility through language of those who move and the dimension of caste and ethnicity: From inside a rural Nepali community. The Himalayan Review, 31: 1-36.

Subedi, B. P. (2007). Migration and tourism in the Trans-Himalayan Region: Studies on changing livelihood patterns of Upper Manang Community in Nepal. In R. P. Chaudhary, T. H. Aase, O. R. Vetaas \& B. P. Subedi. (Eds), Local effects of global changes in the Himalayas: Manang, Nepal, UNIFOB.

Taylor, J. (1998). Measuring short-term population mobility among indigenous Australians: Options and implications. In Australian Geographer, 29 (1) 12537. 
Dhyanendra, Bhim, Hriday Lal/ Territorial mobility ...Vol. 14: 81-112, 2021

Urry, J. (2000). Sociology beyond societies: Mobilities for the twenty-first century. London: Routledge.

Young, E. and Doohan, K. (1989). Mobility for survival: A process analysis of aboriginal population movement in central Australia. Darwin: Australian National University.

Znawali, S. (2033 BS) [1976]. Prithvinarayan Shah (2 ${ }^{\text {nd }}$ Ed.). Darjeeling: Shyam Brothers. 